ICOSITER 2018 Proceeding

Journal of Science and Applicative Technology

\title{
Study of management and development of Observatorium Astronomi ITERA Lampung (OAIL) area: Part I
}

\author{
A N I Putri ${ }^{*}$, W Z Ilmi ${ }^{2}$, A Vatikawa ${ }^{3}$, and N Pratiwi ${ }^{1}$ \\ ${ }^{1}$ Atmospheric and Planetary Sciences Study Program, Institut Teknologi Sumatera, \\ Lampung Selatan, Lampung, Indonesia \\ ${ }^{2}$ Urban and Regional Planning Study Program, Institut Teknologi Sumatera, Lampung \\ Selatan, Lampung, Indonesia \\ ${ }^{3}$ Law Study Program, Universitas Lampung, Bandar Lampung, Lampung, Indonesia \\ *Email: annisa.putri@aps.itera.ac.id
}

\begin{abstract}
Institut Teknologi Sumatera (ITERA) and Institut Teknologi Bandung (ITB) also Government of Lampung Province have launched the ITERA Astronomical Observatory or known with Observatorium Astronomi ITERA Lampung (OAIL). On $20^{\text {th }}$ November 2016, the coordinates of the observatory were determined $05^{\circ} 27^{\prime} 71^{\prime \prime} \mathrm{S}$ and $105^{\circ} 09^{\prime} 39^{\prime \prime}$ E with height of 1030 above sea level. Development of OAIL area will be the center of education in science field especially in Atmospheric and Planetary Sciences. OAIL also will become the center of ecotourism in Lampung Province which can become a tourist attraction for the people in Lampung even outside Lampung. Therefore, it is necessary that management and development be directed so that the main function of the observatory is not disturbed. In this research will do assessment about OAIL area by distribute questionnaire to some related agencies to evaluate whether OAIL area can be a specific area or not. From 50 respondents, there are 35 respondents say that OAIL area is appropriate as a specific area and 15 respondents say vice verca.
\end{abstract}

\section{Introduction}

Institut Teknologi Sumatera (ITERA), Institut Teknologi Bandung (ITB), and Government of Lampung Province have launched the ITERA Astronomical Observatory - Earth and Space Education Center in Sumatera (IAO-ESSECS) or known as Observatorium Astronomi ITERA Lampung (OAIL) at Wan Abdul Rachman Forest Park, Mount Betung, Lampung Province. Development of OAIL area will be as center of sciences International level. Ecotourism aspect also be developed as accommodation for public outreach in sciences field that can attract local and international visitors. Based on Bosscha observatory as protected cultural heritage by Law Number 2 Year 1992 (https://bosscha.itb.ac.id/id/index.php/tentang-bosscha/) ${ }^{[1]}$, do not deny if OAIL will be as second generation of Bosscha that should be protected and maintained its existence from internal and external disturbance such as rapid population development which can impact non-optimal observatory performance.

Furthermore, Wan Abdul Rachman Forest Park is also one of protected forest designated as conservation forest area (Minister of Forestry Decree Number 408 Year $1993{ }^{[2]}$ ) and this area quite apprehensive. Forest cover has been converted into other forms. At present, it is estimated that only $35 \%$ area is still forested, the other is deformed area into mixed gardens, farms, and settlements or gutters 
(Armen Y, $2011^{[3]}$ ). Wan Abdul Rachman Forest Park and other conservation areas are common assets by the government with the aim of conserving biodiversity and environmental services. Wan Abdul Rachman Forest Park is specifically set for the purpose of collecting natural and non-natural plants, animals, native or non-native species which are used for research, education, cultivation support, culture, tourism, and recreation.

One of way to protect and maintain observatory is by making development observatory area as specific area (Niken K and Hani B, $2010^{[4]}$ ). Management and directed development for the OAIL area is needed to control undesirable development. Each criterion in specific area should be assessed so that a decision is made which can then be used as a protected and maintained building, what kind maintained building, and what kind of appropriate management for the construction OAIL area.

\section{Method}

\subsection{Specific Area}

To succeed Wan Abdul Rachman Forest Park program, the OAIL area must be as a specific area determined area that has strategic value in which spatial planning is prioritized (Law Number 26 Year $\left.2007^{[5]}\right)$. For examples are large-scale economic development areas, protection of national culture, nature conservation, and nature reserves. Specific area criteria are (Kodoatie $J$ and Sjarief R, $2010^{[6]}$ ):

a. Regions that have a scale of production activities and/or potential natural resources, artificial resources, and large human resources and influence the development of economic, demographic, political, defense and security aspects, and the development of the surrounding region.

b. Regions that have a scale of production activities and/or the potential of natural resources, artificial resources, and large human resources as well as their business and/or activities have a significant and important impact on similar activities and other activities both in region, surrounding area and the country's territory.

c. Areas that have a big driving factor for improving the socio-economic welfare of the community both in the region and surrounding area.

d. Areas that have relation with activities carried out in other regions bordering both nationally and regionally.

e. Areas that have a strategic position and their business and/or activities have a significant and important impact on national and regional political and defense conditions.

\subsection{Method}

Determination of the type OAIL area is based on primary data. Primary data obtained directly in the field through questionnaires with respondent from related government services. The respondents are from Ministry of Forestry Lampung Province, Ministry of Environmental Lampung Province, Ministry of Public Works and Housing Lampung Province, and Regional Disaster Management Agency Lampung Province. The steps of method to analyse each questionnaire are:

a. Assessment of each criterion from specific area will be rated between 1 to 5 with the provisions not appropriate, less appropriate, quite appropriate, appropriate, and very appropriate.

b. The final value $(\mathrm{Y})$ is obtained by multiplying the value of each criterion by giving simple weight. If assessment value each criterion has 4 or 5 so the value will be multiplied by 5 , if assessment value each criterion has 3 so the value will be multiplied by 3 , and if assessment value each criterion has 1 or 2 so the value will be multiplied by 1 .

c. Class classifications that want to be achieved from this research are two classes (appropriate and not appropriate as specific area). So, it is necessary to determine class interval by reducing the highest final value with the lowest final value then divided by class classification (two).

$$
\text { Class Interval }=\frac{\text { Highest Value-Lowest Value }}{\text { Number of Class }}
$$


d. Final result (appropriate and not appropriate) can be get by reducing the highest value from all criterias with class interval.

$$
\text { Highest Value - Class Interval }=X
$$

If the final value of each criterion (Y) is bigger equal to the $\mathrm{X}$ so OAIL area appropriate to be specific area but if $\mathrm{Y}$ is smaller than X, OAIL area is not appropriate to be specific area.

\section{Result}

From research result, the questionnaire data from four respondents. They are Ministry of Forestry Lampung Province, Ministry of Environmental Lampung Province, Ministry of Public Works and Housing Lampung Province, and Regional Disaster Management Agency Lampung Province. The number of the data from questionnaire are 50 respondents. The distribution number of respondents who filled the questionnaire in each institution can be seen at Table 1.

Table 1. Distribution Number of Respondent.

\begin{tabular}{clc}
\hline No & \multicolumn{1}{c}{ Institution } & $\begin{array}{c}\text { Number of } \\
\text { Respondent }\end{array}$ \\
\hline $\mathbf{1}$ & Ministry of Forestry Lampung Province & 15 \\
$\mathbf{2}$ & Ministry of Environmental Lampung Province & 11 \\
$\mathbf{3}$ & Ministry of Public Works and Housing Lampung Province & 12 \\
$\mathbf{4}$ & Regional Disaster Management Agency Lampung Province & 12 \\
\cline { 2 - 3 } & Total & $\mathbf{5 0}$ \\
\hline
\end{tabular}

The questionnaire data are processed based on method that has been explained before (Part 2). The result is 35 respondents agree that OAIL area appropriate as specific area and 15 respondents do not agree if OAIL area appropriate as specific area. From 15 respondents who do not agree, 50\% respondents come from Regional Disaster Management Agency Lampung Province (Table 2). This result form Regional Disaster Management Agency Lampung Province maybe happen because OAIL area is located at Betung Mount where has high elevation angle. Some of disasters such as erosion and earthquake will have big effect to this area. But, overall from this research, $70 \%$ respondents agree that OAIL area appropriate as specific area. Means that management and development OAIL area can be do more controlled and directed so the main function from observatory is not disturbed.

Table 2. The Result of Suitability OAIL Area as Specific Area.

\begin{tabular}{|c|c|c|c|}
\hline No & Institution & Appropriate & $\begin{array}{c}\text { Not } \\
\text { Appropriate }\end{array}$ \\
\hline 1 & Ministry of Forestry Lampung Province & 13 & 2 \\
\hline 2 & Ministry of Environmental Lampung Province & 9 & 2 \\
\hline 3 & Ministry of Public Works and Housing Lampung Province & 9 & 3 \\
\hline \multirow[t]{2}{*}{4} & Regional Disaster Management Agency Lampung Province & 4 & 8 \\
\hline & Total & 35 & 15 \\
\hline
\end{tabular}




\section{Conclusion}

ITERA Astronomical Observatory - Earth and Space Education Center in Sumatera (IAO_ESSECS) or known as Observatorium Astronomi ITERA Lampung (OAIL) will be developed by Institut Teknologi Sumatera (ITERA), Institut Teknologi Bandung (ITB), and Government of Lampung Province. OAIL area will be as centre of science internationally. Moreover, ecotourism aspect also will be developed as accommodation for public outreach in science filed that can attract local and international visitors. This research has purpose to know whether OAIL area can be as specific area or not to control its development and maintenance by distributing questionnaire to Ministry of Forestry Lampung Province, Ministry of Environmental Lampung Province, Ministry of Public Works and Housing Lampung Province, and Regional Disaster Management Agency Lampung Province. From total 50 respondents, $70 \%$ respondents agree that OAIL area appropriate as specific area. Means that management and development OAIL area can be do more controlled and directed so the main function from observatory is not disturbed.

\section{Acknowledgement}

Author would like to thank The Research Institute and Community Services (LP3) Institut Teknologi Sumatera (ITERA) who helped during the process of this research so that this research can be done smoothly.

\section{References}

[1] https://bosscha.itb.ac.id/id/index.php/tentang-bosscha/

[2] Minister of Forestry Decree Number 408 Year 1993

[3] Yasir A 2011 Academic Manuscript of Collaborative Management of Wan Abdul Rachman Forest Park in Lampung Province, Universitas Lampung, Bandar Lampung

[4] Katrini N and Burhanudin H 2010 Jurnal Perencanaan Wilayah dan Kota. Universitas Islam Bandung 101

[5] Law Number 26 Year 2007 concerning Spatial Planning (State Gazette of The Republic Indonesia Year 2009 Number 11, Supplement to The State Gazette of The Republic Indonesia Number 4725)

[6] Kodoatie R J and Sjarief R 2010 Tata Ruang Air (Yogyakarta: Andi Publisher) 